\title{
Expression of the Pseudomonas Gene Coding for Carboxypeptidase G2 in Saccharomyces cerevisiae
}

\author{
By LORRAINE E. CLARKE, ${ }^{1}{ }^{*}+$ RAYMOND F. GIBSON, ${ }^{2}$ \\ ROGER F. SHERWOOD ${ }^{1}$ AND NIGEL P. MINTON ${ }^{1}$ \\ ${ }^{1}$ Microbial Technology Laboratory, PHLS Centre for Applied Microbiology and Research, \\ Porton Down, Salisbury, Wiltshire SP4 OJG, UK \\ ${ }^{2}$ Cadbury Schweppes Group Research, The Lord Zuckerman Research Centre, The University, \\ Whiteknights, Reading RG6 $2 L A, U K$
}

(Received 17 September 1984 ; revised 5 November 1984)

The Pseudomonas gene coding for carboxypeptidase G2 was introduced into Saccharomyces cerevisiae on an Escherichia coli/yeast shuttle vector pROG5. The level of enzyme activity obtained was independent of the orientation of the gene within the pBR322-derived tetracycline resistance gene of the vector, indicating that expression can occur from a Pseudomonas promoter in yeast.

\section{INTRODUCTION}

The enzyme carboxypeptidase G2 (CPG2) from Pseudomonas hydrolyses the C-terminal glutamate moiety from folic acid and its analogues. Carboxypeptidase $\mathrm{G}$ enzymes have been used for rescue therapy of patients suffering methotrexate toxicity during chemotherapy, and animal studies have shown that the enzymes themselves, by depleting the levels of circulating folate, have antitumour properties (Kalghatgi \& Bertino, 1981). In order to increase yields of CPG2 so as to provide sufficient material for a full assessment in clinical trials, the gene coding for CPG2 has recently been cloned in Escherichia coli (Minton et al., 1983), where it is expressed at $3-5 \%$ of the soluble protein. The nucleotide sequence has been determined (Minton et al., 1984 ) and the coding region consists of $1.24 \mathrm{~kb}$ of DNA, including a coding region for a signal peptide of 22 amino acids at its $\mathrm{N}$-terminus. The enzyme is located in the periplasmic space in both Pseudomonas and E. coli (Minton et al., 1983).

Interest in yeast as an alternative host to $E$. coli has escalated in recent years and several commercially important products from eukaryotic sources have been cloned in Saccharomyces cerevisiae (Hitzeman et al., 1981; Derynck et al., 1983; Miyanohara et al., 1983; Mellor et al., 1983). In addition, there are now reports in the literature of both plasmid-derived (Hollenberg, 1979; Cohen et al., 1980; Jiminez \& Davies, 1980; Roggenkamp et al., 1981; Cohen et al., 1983; Gritz \& Davies, 1983) and chromosomally-derived (Panthier et al., 1980; Janowicz et al., 1982; Fehor et al., 1983) prokaryotic genes being functionally expressed in yeast. Studies on the expression of heterologous genes in alternative hosts are providing valuable information for interpreting the requirements for gene expression and the subsequent processing of the products.

In this report, we show that the CPG2 gene from Pseudomonas is functionally expressed in $S$. cerevisiae. This is significant both in considering yeast as a possible alternative host for the production of CPG2 and other proteins, and in facilitating further studies on the nature of gene expression and protein processing in yeast.

† Present address: Parasitology Department, Houghton Poultry Research Station, Houghton, Huntingdon, Cambs. PE17 2DA, UK.

Abbreviation: CPG2, carboxypeptidase G2. 


\section{METHODS}

Bacterial and yeast strains. The strains used were E. coli JA221 (recA1 leuB6 trp $\Delta E 5$ hsdR $\mathrm{M}^{+}$lacY $\left.\mathrm{C} 600\right)$ and $S$. cerevisiae LL20 (MAT leu2-112 leu2-3 his3-11 his3-15 [2 $\left.\mathrm{m}^{+}\right]$).

Plasmids. The structures of the plasmids used are shown in Fig. 1. The $S$. cerevisiae/E. coli shuttle vector, pROG5, was constructed by inserting the $3.2 \mathrm{~kb}$ HindIII fragment of pJDB219 (Beggs, 1978), containing the leu2 gene of $S$. cerevisiae and the replication origin of the $2 \mu \mathrm{m}$ plasmid, into the HindIII site of pBR322 (Bolivar et al., 1977).

The coding sequences for the promoter, signal peptide and complete structural gene of CPG2 are contained within a $2.034 \mathrm{~kb} \mathrm{BamHI}$ restriction fragment isolated from the recombinant plasmid pNM15 (Minton \& Clarke, 1985). The recombinant plasmids pLEC 3 and pLEC4 were constructed by inserting this fragment, in both orientations, into the BamHI site within the tetracycline resistance gene (tet) of pROG5.

Media and culture conditions. Cultures of $E$. coli for plasmid isolation were grown at $37^{\circ} \mathrm{C}$ in L-broth $(1 \%$ tryptone (w/v), $0.5 \%$ yeast extract, $0.5 \% \mathrm{NaCl})$, to which Bactoagar $(2 \%$, w/v) was added for solid media. Minimal medium for $E$. coli was M9 (Miller, 1972) with $0.2 \%$ folic acid added where appropriate. Ampicillin $\left(50 \mu \mathrm{g} \mathrm{ml}^{-1}\right)$ and tetracycline $\left(15 \mu \mathrm{g} \mathrm{ml}^{-1}\right)$ were used for the selection of transformants.

Yeast cells were grown at $30^{\circ} \mathrm{C}$ on complete YEPD medium $[1 \%$ yeast extract $(w / v), 2 \%$ peptone $(w / v), 2 \%$ glucose $(w / v)]$. Solidified medium consisted either of YEPD or selective YNB medium with the addition of $3 \%$ ( $w / v)$ Bactoagar [YNB contains $0.67 \%$ yeast nitrogen base without amino acids (Difco), $2 \%$ glucose ( $w / v)$ and the required amino acids to $20 \mathrm{\mu g} \mathrm{ml}^{-1}$ ]. In order to screen for the $\mathrm{Fol}^{+}$phenotype (ability to hydrolyse folic acid) the glucose concentration in YNB medium was reduced to $0.05 \%$ and $0.2 \%$ folic acid was added.

Preparation of plasmid DNA. Plasmids were isolated from chloramphenicol-amplified cultures of $E$. coli by Brij lysis (Clewell \& Helinski, 1969) and caesium chloride/ethidium bromide density gradient centrifugation (Colman et al., 1978). The small-scale plasmid isolation procedure of Holmes \& Quigley (1981) was used for rapid screening of transformants.

Small-scale preparations of plasmids from $S$. cerevisiae were made by suspending an inoculating loop of cells in $100 \mu 1$ spheroplasting buffer (1.0 M-sorbitol, $25 \mathrm{mM}$-EDTA, $67 \mathrm{mM}$-phosphate buffer $\mathrm{pH} 7.5$ and $5 \mathrm{mg}$ Zymolyase $60000 \mathrm{ml}^{-1}$ ). The spheroplasts were lysed by the procedure of Birnboim \& Doly (1979). The final pellet was resuspended in $20 \mu \mathrm{l}$ TE buffer $(10 \mathrm{mM}-\mathrm{Tris} / \mathrm{HCl} \mathrm{pH} 8.0,1 \mathrm{mM}-\mathrm{EDTA})$ and emulsified with $20 \mu \mathrm{l}$ chloroform/ isoamyl alcohol $(24: 1, \mathrm{v} / \mathrm{v})$. Following centrifugation, the plasmid-containing phase was used to transform competent $E$. coli cells. (This procedure was a personal communication from N. Urwin, Charing Cross Hospital, London, UK.)

Restriction, ligation and transformation procedures. Restriction enzymes and DNA ligase were purchased from Bethesda Research Laboratories, and were used according to the manufacturer's instructions. $E$. coli was transformed essentially as described by Cohen et al. (1972). Transformants were selected on ampicillin and screened for tetracycline sensitivity and the $\mathrm{Fol}^{+}$phenotype, which is evident on folate-containing agar medium as concentric yellow haloes of precipitated pteroic acid (Minton et al., 1983). Transformation of $S$. cerevisiae was mediated by lithium acetate as described by Ito et al. (1983) and the transformants were screened for the $\mathrm{Leu}^{+} \mathrm{Fol}^{+}$ phenotype.

Determination of CPG2 activity. Bacteria or yeast were grown in $500 \mathrm{ml}$ batch cultures. Samples $(100 \mathrm{ml})$ were centrifuged at $8000 \mathrm{~g}$ for $10 \mathrm{~min}$ and resuspended in $5 \mathrm{ml} 0.1 \mathrm{M}$-Tris $/ \mathrm{HCl} \mathrm{pH} 7.3$ containing $0.2 \mathrm{M}-\mathrm{ZnSO}_{4}$. The cells were disrupted by two passages through a French press at $1250 \mathrm{lbf} \mathrm{in}^{-2}(8.63 \mathrm{MPa})$. The cell debris was removed by centrifugation at $10000 \mathrm{~g}$ for $10 \mathrm{~min}$ and the supernatant was assayed for CPG2 activity by the method of McCollough et al. (1971) as described by Minton et al. (1983) (one unit represents the hydrolysis of $1 \mu$ mole of methotrexate per min at $37^{\circ} \mathrm{C}$ ). Protein was determined by the method of Bradford (1976).

\section{RESULTS AND DISCUSSION}

The shuttle vector pROG5 continues to express resistance to tetracycline at up to $60 \mu \mathrm{g} \mathrm{ml}^{-1}$ despite the insertion of a fragment of yeast DNA into the HindIII site within the promoter of the gene (Backman \& Boyer, 1983). This is almost certainly due to the reconstitution of a functional tet promoter as a result of the fortuitous presence of promoter-like sequences in the inserted $2 \mu \mathrm{m}$ DNA. Two conserved regions are known to be important for transcription initiation in prokaryotes: the sequences of the -35 and -10 regions relative to the start point of mRNA transcription, whose consensus sequences are TTGACA and TATAAT respectively (for review see Von Hippel et al., 1982). The restriction enzyme HindIII cleaves immediately before the -10 region of the tet promoter (Fig. 2). The $2 \mu \mathrm{m} \mathrm{DNA}$ inserted into the HindIII site, however, carries a pseudo -35 region TAGTCA, separated from the tet promoter -10 region by a spatially acceptable 16 nucleotides. The $2 \mu \mathrm{m}$ DNA sequence TTAGTC which is $17 \mathrm{bp}$ from the 


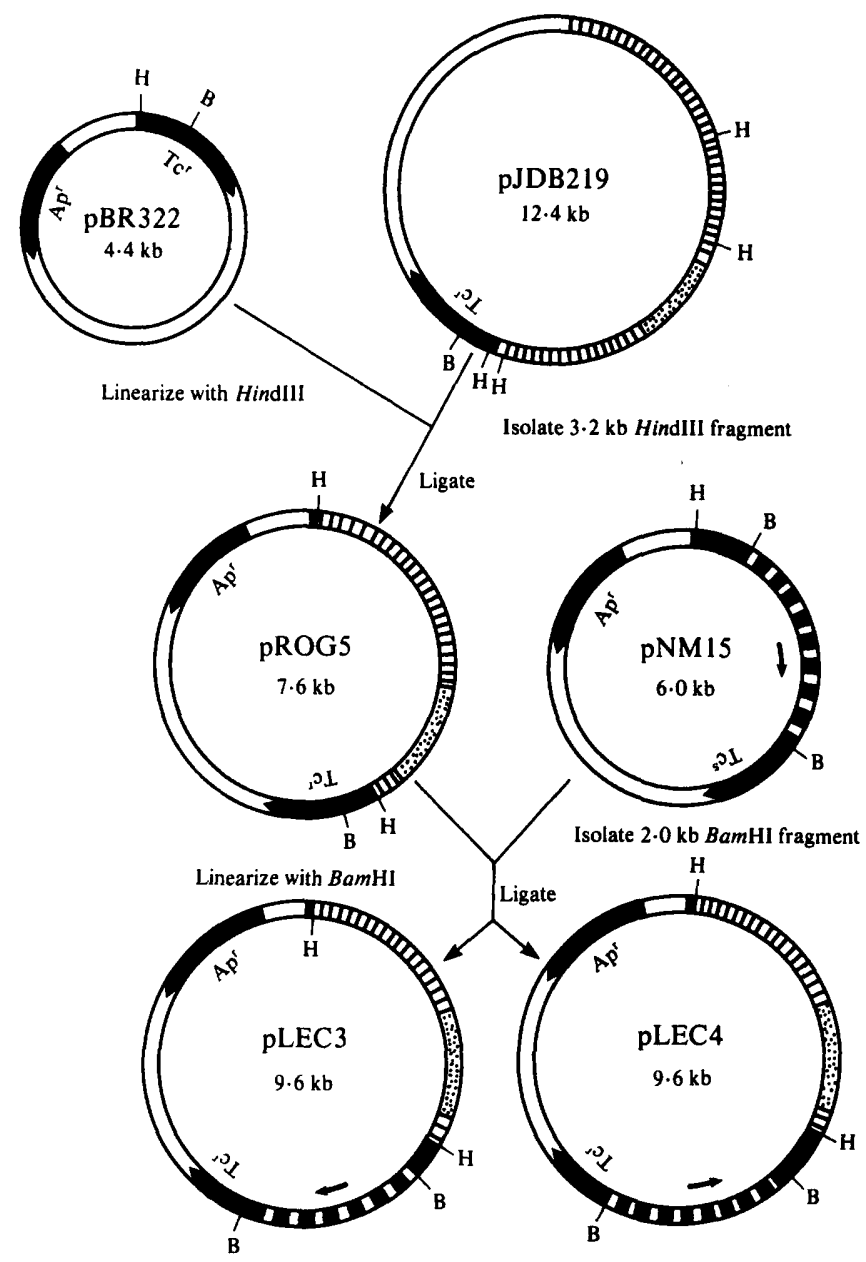

Fig. 1. Derivation of the $S$. cerevisiae/E. coli shuttle vector pROG5 and the recombinant plasmids pLEC 3 and pLEC4. Arrows indicate the relative orientations of the tetracycline (Tc) and ampicillin (Ap) resistance genes within the plasmids. Antibiotic resistance genes; 110 , yeast $2 \mu \mathrm{m}$ plasmid; ㄷ, CPG2 gene; $\$$, yeast chromosomal leu2 gene; $\square$, pMB9 in pJDB219, pAT153 in pNM15, pBR322 elsewhere. H, HindIII cleavage site; B, BamHI cleavage site.

pBR322

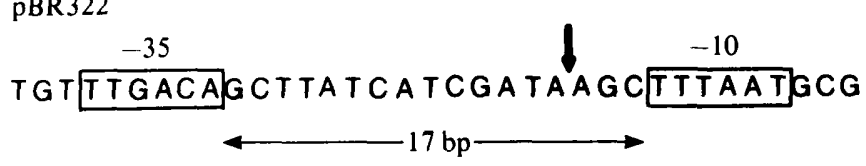

pROG5

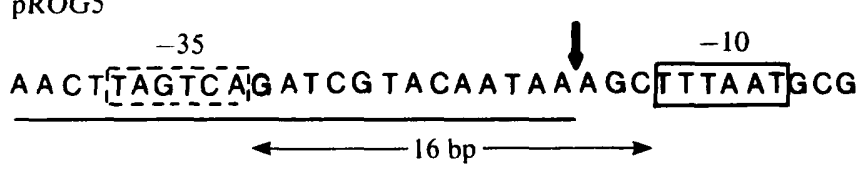

Fig. 2. Comparison of the nucleotide sequence of the tetracycline gene promoter from pBR322 and the same region in pROG5. The sequence of pBR322 was taken from Sutcliffe (1978) and that of the yeast $2 \mu \mathrm{m}$ plasmid from Hartley \& Donelson (1980). Nucleotides derived from the yeast $2 \mu \mathrm{m}$ plasmid are underlined. The vertical arrows indicate the cleavage site of HindIII. 
-10 region presents a second, though less likely, possibility. Similar -35 sequences have been observed on other prokaryotic promoters (Rosenberg \& Court, 1979; Siebenlist et al., 1980). The deviation of the possible pseudo -35 sequences from the known and consensus -35 sequences of the tet promoter (TTGACA) suggests that the promoter created would be less efficient than the natural promoter of the tet gene.

The CPG2 gene was introduced into pROG5 as described in Methods, and was characterized in $E$. coli and subsequently transformed into $S$. cerevisiae. In $E$. coli the level of expression of CPG2 was dependent on the orientation of the gene within the vector. Enzyme assays on cell extracts showed that pLEC3 directed the expression of up to 40-fold greater levels of CPG 2 compared to pLEC4. The CPG2 gene in pLEC3 is in the same orientation as the tet gene and the higher level of expression obtained with this plasmid can probably be accounted for by transcriptional readthrough from the tet promoter. This phenomenon has been observed with previous constructs carrying CPG2 inserted into the BamHI site of the pBR322 tet gene (Minton et $a l ., 1983)$. In that instance, the CPG2 gene was transcribed from an unimpaired tet promoter and the orientation-dependent effect resulted in a 1000-fold difference in the level of enzyme activity.

Transformation of the plasmids pLEC 3 and pLEC4 into yeast resulted in Leu ${ }^{+}$colonies, $90 \%$ of which turned yellow after $48 \mathrm{~h}$ in the presence of folate, indicating the Fol ${ }^{+}$phenotype. Plasmids isolated from the $\mathrm{Leu}^{+} \mathrm{Fol}^{+}$colonies were transformed into $E$. coli and screened by restriction analysis for the presence of an intact CPG2 gene. No deviations from the original plasmids used to transform the $S$. cerevisiae cells were identified.

The ability of $S$. cerevisiae cells to grow on folate in the presence or absence of the CPG2 gene was examined in detail (Table 1). Cells carrying either pLEC3 or pLEC4 grew very poorly on folate as the sole carbon and nitrogen source and required $0.05 \%$ glucose for the demonstration of the $\mathrm{Fol}^{+}$phenotype. At high concentrations of glucose $(0.5 \%)$ and under conditions of limited nitrogen, yeast cells transformed with pROG5 alone became orange in the presence of folate. This was accompanied by the formation of a transparent halo in the medium around the colonies, indicating that folate had been taken up from the plates, but not hydrolysed. The orange coloration observed in such cells was distinct from the diffuse bright yellow coloration of cells carrying the CPG2 gene and hydrolysing folate to pteroate. These results suggest that $S$. cerevisiae has an energy dependent uptake of folate and can accumulate folate. An energy requirement for the uptake of folate has previously been demonstrated in murine leukaemia cells and in lactobacilli (Huennekens et al., 1978).

In contrast to $E$. coli, there was no orientation-dependent expression of CPG2 in S. cerevisiae, as cells carrying either pLEC 3 or pLEC4 demonstrated similar levels of enzyme activity (Table 2). This suggests that CPG2 is expressed entirely from its own promoter in $S$. cerevisiae. Although the low specific activity of CPG2 in yeast cells prevented selection for the plasmid in minimal medium in liquid culture, replica plating of isolated colonies onto folate minimal medium demonstrated that at least $70 \%$ of the cells still had the $\mathrm{Fol}^{+}$phenotype after $5 \mathrm{~d}$ continuous sub-culturing at $30^{\circ} \mathrm{C}$ in shake flasks.

In $S$. cerevisiae the maximum levels of enzyme activity were observed after $48 \mathrm{~h}$ in liquid culture, compared to approximately $6 \mathrm{~h}$ in $E$. coli (Table 2) (Minton et al., 1983). The highest specific activity observed was about 0.03 units (mg protein $)^{-1}$, representing approximately $0.005 \%$ of the soluble protein. This is of a similar order to the activity measured when the gene was expressed from its own promoter in $E$. coli, where it represented $0.01 \%$ of the soluble protein (Table 2) (Minton et al., 1983).

This report contains the first published evidence of a gene isolated from Pseudomonas being expressed in $S$. cerevisiae and provides evidence that some expression can occur from a Pseudomonas promoter in yeast. Mapping of the transcripts of the $E$. coli $\beta$-lactamase gene in $S$. cerevisiae has indicated that $S$. cerevisiae RNA polymerase can recognize sequences at or near $E$. coli promoters (Breunig et al., 1982). However, recent promoter mapping studies of the CPG2 gene have shown that CPG2 does not possess a typical E. coli-type promoter (Minton \& Clarke, 1985). This may account, at least in part, for the low levels of expressions of this gene in $E$. coli and could contribute to the similarly low levels found in $S$. cerevisiae. Attention has also been drawn 
Table 1. Phenotype of $S$. cerevisiae cells in the presence or absence of CPG2 when grown on folate and various concentrations of glucose as sole carbon and nitrogen sources

$S$. cerevisiae cells carrying the CPG2 gene were grown on solidified minimal medium in the presence of leucine, histidine and $0.2 \%$ folic acid, but in the absence of any other carbon or nitrogen source. A range of concentrations of glucose was evaluated for its effect on growth and demonstration of the Fol ${ }^{+}$ phenotype. + , Poor growth; ++ , reasonable growth; +++ , good growth; W, white; WY, weakly yellow; $Y$, yellow; $\mathrm{O}$, orange.

$\overbrace{\text { Glucose }}^{\begin{array}{c}\text { Carbon and nitrogen } \\ \text { source }(\%, w / v)\end{array}} \begin{array}{cc}\text { Folate } \\ 0 & 0.20 \\ 0.05 & 0.20 \\ 0.10 & 0.20 \\ 0.50 & 0.20 \\ 2.00 & 0.20\end{array}$

\begin{tabular}{|c|c|c|}
\hline \multicolumn{3}{|c|}{ Cells transformed with: } \\
\hline pROG5 & pLEC3 & pLEC4 \\
\hline $\begin{array}{l}++\quad(W) \\
+++(W) \\
+++(W) \\
+++(0) \\
++\quad(0)\end{array}$ & $\begin{array}{l}+\quad(\mathbf{W Y}) \\
++\quad(\mathbf{Y}) \\
+++(\mathbf{Y}) \\
+++(\mathbf{Y}) \\
++\quad(\mathbf{Y})\end{array}$ & $\begin{array}{l}+\quad(\mathbf{W Y}) \\
++\quad(\mathbf{Y}) \\
+++(\mathbf{Y}) \\
+++(\mathbf{Y}) \\
++\quad(\mathbf{Y})\end{array}$ \\
\hline
\end{tabular}

Table 2. Specific activity of CPG2 in cell extracts from $E$. coli and $S$. cerevisiae carrying either pLEC3 or $p L E C 4$

$E$. coli cells were grown at $37^{\circ} \mathrm{C}$ in L-broth, in the presence of ampicillin, in shake flasks. S. cerevisiae cells were similarly grown at $30^{\circ} \mathrm{C}$ in YEPD medium. The cells were disrupted and CPG2 assayed as described in Methods. No CPG2 activity was detected in control cultures of cells carrying pROG5 alone.

$\begin{array}{lccc}\text { Host } & \begin{array}{c}\text { Time } \\ \text { (h) }\end{array} & \overbrace{\text { pLEC3 }}^{\text {Specific activity }} & \text { pLEC4 } \\ \text { [Units (mg protein) } & \text { pl] } \\ \text { E. coli } & 6 & 0.177 & 0.003 \\ & 24 & 0.090 & 0.021 \\ \text { S. cerevisiae } & 48 & 0.040 & 0.004 \\ & 6 & 0.006 & 0.012 \\ & 24 & 0.009 & 0.010 \\ & 48 & 0.020 & 0.028 \\ & 72 & 0.008 & 0.026\end{array}$

to an interesting feature of the CPG2 promoter by the recent observation of Johnston \& Downie (1984) that a region in the promoter of the Pseudomonas xylABC operon (Inouye et al., 1984) conforms to the consensus sequence for the regulatory region in the promoters of the nif genes in Rhizobium and Klebsiella. A similar sequence occurs in the CPG2 promoter (Minton \& Clarke, 1985), raising interesting possibilities concerning the control of this gene, both in Pseudomonas and in heterologous hosts.

It is not yet known whether CPG2 activity in yeast is due to enzymic activity of the preprotein or if the yeast cell has processed the preprotein to mature enzyme. The $E$. coli preproteins of $\beta$ lactamase (Roggenkamp et al., 1981) and the outer-membrane protein Omp A (Janowicz et al., 1982) can be processed in $S$. cerevisiae. We are working currently to increase the levels of expression of CPG2 in yeast by the use of high expression vectors containing yeast promoters and to examine the processing and localization of the enzyme in the yeast cell.

L.E.C. acknowledges receipt of a grant from the Health and Safety Executive.

\section{REFERENCES}

BACkman, K. \& Boyer, H. W. (1983). Tetracycline resistance determined by pBR 322 is mediated by one polypeptide. Gene 26, 197-203.
BEgGS, J. D. (1978). Transformation of yeast by a replicating hybrid plasmid. Nature, London 275, 104 108. 
Birnboim, H. C. \& Doly, J. (1979). A rapid alkaline extraction procedure for screening recombinant plasmid DNA. Nucleic Acids Research 7, 1513-1523.

Bolivar, S., Rodriguez, R. L., Green, P. J., Betlach, M. C., Heynecker, H. L., BOYer, H. W., Crosa, J. H. \& Falkow, S. (1977). Construction and characterization of new cloning vehicles. II. A multipurpose cloning system. Gene 2, 95-113.

BraDFord, M. M. (1976). A rapid and sensitive method for the quantitation of microgram quantities of protein utilising the principle of protein-dye binding. Analytical Biochemistry 72, 248-254.

Breunig, K. D., MaCKedonski, V. \& HollenberG, C. P. (1982). Transcription of the bacterial $\beta$ lactamase gene in Saccharomyces cerevisiae. Gene 20 , $1-10$.

Clewell, D. B. \& Helinski, D. R. (1969). Supercoiled circular DNA-protein complex in $E$. coli. Purification and induced conversion to an open circular form. Proceedings of the National Academy of Sciences of the United States of America 62, 1159-1166.

Cohen, S. N., Chang, A. C. Y. \& Shu, L. (1972). Nonchromasomal antibiotic resistance in bacteria: genetic transformation of $E$. coli by R-factor DNA. Proceedings of the National Academy of Sciences of the United States of America 69, 2110-2114.

Cohen, J. D., Eccleshall, T. R., Needleman, R. B., Federoff, H., Buchferer, B. A. \& Marmur, J. (1980). Functional expression in yeast of the gene coding for chloramphenicol acetyltransferase. Proceedings of the National Academy of Sciences of the United States of America 77, 1078-1082.

Cohen, J. D., Abrams, E., Eccleshall, T. R., BUCHFERER, B. \& MARMUR, J. (1983). Expression of a prokaryotic gene in yeast: isolation and characterisation of mutants with increased expression. Molecular and General Genetics 191, 451-459.

Colman, A., Beyers, M. J., Primrose, S. B. \& Lyons, A. (1978). Rapid purification of plasmid DNA's by hydroxyapatite chromatography. European Journal of Biochemistry 91, 303-310.

DERYNCK, R., SinGH, A. \& GoEdDEL, D. V. (1983). Expression of human interferon-gamma cDNA in yeast. Nucleic Acids Research 10, 2625-2673.

FehoR, Zs., Kiss, A. \& Venetianer, P. (1983). Expression of a bacterial modification methylase in yeast. Nature, London 302, 366-368.

GritZ, L. \& DAviES, T. (1983). Plasmid encoded hygromycin B resistance: the sequence of hygromycin B phosphotransferase and its expression in Escherichia coli and Saccharomyces cerevisiae. Gene 25, 179-188.

Hartley, J. L. \& Donelson, J. E. (1980). Nucleotide sequence of the yeast plasmid. Nature, London 286 , $860-865$.

Hitzeman, R., Hagie, F. E., Levine, H. L., Goeddel, D. V., Ammerer, G. \& Hall, B. D. (1981). Expression of a human gene for interferon in yeast. Nature, London 293, 717-722.

HollenberG, C. P. (1979). The expression of bacterial antibiotic resistance genes in the yeast Saccharomyces cerevisiae. In Plasmids of Medical, Environmental and Commercial Importance, pp. 481-492. Edited by K. N. Timmis \& A. Puhler. Amsterdam: Elsevier/North Holland Biomedical Press.

Holmes, D. S. \& QUigLEY, M. (1981). A rapid boiling method for the preparation of bacterial plasmids. Analytical Biochemistry 114, 193-197.

Huennekens, F. M., Vitols, K. S. \& Henderson, G. B. (1978). Transport of folate compounds in bacterial and mammalian cells. Advances in Enzymo$\log y$ 47, 313-346.

InOUYe, S., Ebina, Y., Nakazawa, A. \& Nakazawa, T. (1984). Nucleotide sequence surrounding transcription initiation site of $x y$ lABC operon in TOL plasmid of Pseudomonas putida. Proceedings of the National Academy of Sciences of the United States of America 81, 1688-1691.

Ito, H., Fukuda, Y., Murata, K. \& Kimura, A. (1983). Transformation of intact yeast cells treated with alkali cations. Journal of Bacteriology 153, 163168.

Janowicz, Z. A., Henning, U. \& Hollenberg, C. P. (1982). Synthesis of Escherichia coli outer membrane OmpA protein in yeasts. Gene 20, 347-358.

Jiminez, A. \& DAvies, J. (1980). Expression of a transposable antibiotic resistance element in Saccharomyces. Nature, London 287, 869-871.

Johnston, A. W. B. \& DowniE, J. A. (1984). What is a nif promoter? Trends in Biochemical Sciences 9, 366367.

Kalghatgi, K. K. \& Bertino, J. R. (1981). Folatedegrading enzymes: a review with special emphasis on carboxypeptidase G. In Enzymes as Drugs, pp. 77-102. Edited by J. S. Holcenberg \& J. Roberts. New York: John Wiley.

McCollough, J. L., Chabner, B. A. \& Bertino, J. R. (1971). Purification and properties of carboxypeptidase G1. Journal of Biological Chemistry 246, 72077213.

Mellor, J., Dobson, M. J., Roberts, N. A., Tuite, M. F., Emtage, J. S., White, S., Lowe, P. A., Patel, T., Kingsman, A. J. \& Kingsman, S. M. (1983). Efficient synthesis of enzymatically active calf chymosin in Saccharomyces cerevisiae. Gene 24, 1-14.

Miller, J. (1972). Experiments in Molecular Genetics. Cold Spring Harbor, NY: Cold Spring Harbor Laboratory.

Minton, N. P. \& Clarke, L. E. (1985). Identification of the promoter of the Pseudomonas gene coding for carboxypeptidase G2. Journal of Molecular and Applied Genetics (in the press).

Minton, N. P., Atkinson, A. \& Sherwood, R. F. (1983). Molecular cloning of the Pseudomonas carboxypeptidase G2 gene and its expression in Escherichia coli and Pseudomonas putida. Journal of Bacteriology 156, 1222-1227.

Minton, N. P., Atkinson, A., Bruton, C. J. \& SHERWOOD, R. F. (1984). The complete nucleotide sequence of the Pseudomonas gene coding for carboxypeptidase G2. Gene 31, 31-38.

Miyanohara, A., Toh-E, A., Nozai, C., Hamada, F., OHTOMO, N. \& MATSUBARA, K. (1983). Expression of hepatitis B surface antigen in yeast. Proceedings of the National Academy of Sciences of the United States of America 80, 1-5.

Panthier, J. J., Fournier, P., Heslot, H. \& RambaCH, A. (1980). Cloned galactosidase gene of Escherichia coli is expressed in the yeast Saccharomyces cerevisiae. Current Genetics 2, 109-113.

Roggenkamp, R., Birgit, K.-K. \& Hollenberg, C. P. (1981). Expression and processing of the 
bacterial $\beta$-lactamase gene in the yeast Saccharomyces cerevisiae. Proceedings of the National Academy of Sciences of the United States of America 78, 44664470.

Rosenberg, M. \& CourT, D. (1979). Regulatory sequences involved in the promotion and termination of RNA transcription. Annual Review of Genetics 13, 319-353.

Siebenlist, U., Simpson, R. B. \& Gilbert, W. (1980). Escherichia coli RNA polymerase interacts homolo- gously with two different promoters. Cell 20, 269281.

SutCliffe, J. G. (1978). Complete nucleotide sequence of the Escherichia coli plasmid pBR322. Cold Spring Harbor Symposia on Quantitative Biology 43, 77-90.

VoN Hippel, P. H., BEAR, D. G., WinTER, R. B. \& OTTo, G. B. (1982). Molecular aspects of promoter function: an overview. In Promoter Structure and Function, pp. 3-33. Edited by R. L. Rodriguez \& M. J. Chamberlin. New York: Prager Publishers. 